\title{
Geographic variation in the morphology of the sand-dwelling lizard Nothobachia ablephara (Squamata: Gymnophthalmidae)
}

\author{
Carolina Nisa Ramiro, Renato Sousa Recoder, and Miguel Trefaut Rodrigues \\ Departamento de Zoologia, Instituto de Biociências, Universidade de São Paulo, 05508-090, São Paulo, SP, Brazil. \\ E-mail: carolina.nisa@gmail.com.
}

\begin{abstract}
Geographic variation in the morphology of the sand-dwelling lizard Nothobachia ablephara (Squamata: Gymnophthalmidae). Nothobachia ablephara is a small microteiid lizard with an elongated body and reduced limbs; it occurs in isolated dune fields in the state of Bahia (Xique-Xique and Alagoado) and small sandy patches in northeastern Brazil. A previous molecular study found a marked mtDNA divergence between populations of $N$. ablephara from Alagoado and Xique-Xique dunes, suggesting that the two populations diverged from one another between 3 and 4 million years ago. Given this isolation, it is interesting to explore whether morphological traits of the lizards reflect the reported genetic divergence of the populations. Scale counts of the sexes and the populations differ significantly, but there is considerable overlap of values. Univariate and multivariate analyses revealed significant morphometric variation between sexes and populations; however, this is mostly explained by size differences. Females are larger than males in all characters that are sexually dimorphic, and individuals from Xique-Xique are larger than those from Alagoado in all characters that vary geographically. The sample from Alagoado has more sexually dimorphic characters than the one from Xique-Xique. Although $N$. ablephara displays some geographical variation, the two populations could not be unequivocally distinguished by scale counts and morphometric data.
\end{abstract}

Keywords: caatinga, differentiation, dunes, morphometry.

\begin{abstract}
Resumo
Variação geográfica na morfologia do lagarto fossorial Nothobachia ablephara (Squamata: Gymnophthalmidae). Nothobachia ablephara é um pequeno microteídeo de corpo alongado e membros reduzidos que ocorre em campos de dunas isolados no estado da Bahia (Xique-Xique e Alagoado) e em pequenas manchas de areia na região nordeste do Brasil. Dados moleculares mitocondriais encontraram uma divergência significativa entre as populações de $N$. ablephara dos campos de dunas de Xique-Xique e Alagoado, sugerindo que essas duas populações divergiram uma da outra entre três e quatro milhões de anos atrás. Considerando que as populações estão isoladas, é
\end{abstract}

Received 05 November 2018

Accepted 20 September 2019

Distributed December 2019 
interessante explorar se caracteres morfológicos desses lagartos refletem a divergência entre as duas populações reportada pelos dados moleculares. As contagens de escamas mostraram diferenças significantes entre sexos e entre as populações, mas há uma significativa sobreposição dos valores. Análises univariadas e multivariadas revelaram uma variação significativa na morfometria entre sexos e populações que foi principalmente explicada por diferenças de tamanho. Fêmeas são maiores do que os machos em todos os caracteres que são sexualmente dimórficos, e os indivíduos de XiqueXique são maiores do que os de Alagoado em todos os caracteres que mostraram diferenças geográficas. Ademais, a amostra de Alagoado apresentou dimorfismo sexual em maior número de caracteres que a de Xique-Xique. Embora $N$. ablephara tenha exibido variação geográfica significativa, não foi possível distinguir inequivocamente as duas populações com base em contagens de escama e morfometria.

Palavras-chave: caatinga, diferenciação, dunas, morfometria.

\section{Introduction}

Microteiid lizards of the family Gymnophthalmidae (Estes et al. 1988) comprise about 250 species in 48 genera of small to mediumsized lizards (snout-vent length ranging from 3-15 cm) that range from southern Mexico to Argentina (Uetz and Hosek 2018). Most microteiids are terrestrial to semi-fossorial and occupy a wide range of habitats, from open areas in the Andes to lowland rain forests (Pianka and Vitt 2003). Many species are microhabitat specialists-e.g., semi-aquatic (Gelanesaurus, Neusticurus, and Potamites), scansorial (Anadia, Placosoma, and Selvasaura) or fossorial taxa (Bachia, Calyptommatus, Nothobachia, and Scriptosaura) (Rodrigues 1984, 1991a, ÁvilaPires 1995, Rodrigues et al. 2001, Rodrigues and Santos 2008, Moravec et al. 2018); thus, there is convergence of body forms in distantly related groups (Pellegrino et al. 2001, Wiens et al. 2006, Marques-Souza et al. 2018).

The occurrence of convergent characters, especially the recurrent appearance of morphological adaptations to fossoriality, combined with the paucity of many taxa in collections impose difficulties for a morphology-based taxonomy of Gymnophthalmidae (Rodrigues 1991a, Pellegrino et al. 2001). The first contribution to the molecular systematics of Gymnophthalmidae was based on data for 51 species representing 26 genera (Pellegrino et al. 2001). Subsequently, new molecular studies have provided a deeper understanding of the relationships between species and genera of Gymnophthalmidae (Rodrigues et al. 2001, Castoe et al. 2004, Doan and Castoe 2005, Goicoechea et al. 2016, Marques-Souza et al. 2018).

Taxonomy is an important component of biogeography, ecology, conservation, and other biodiversity studies (Ebach et al. 2011). Historically, herpetological studies focused on morphological data to assess the relationships among taxa, and traditional characters such as cephalic scales, number of dorsal and ventral scales, presence or absence of morphological structures and color pattern were commonplace for species recognition in microteiids (Rodrigues 1984, 1991a-c, Rodrigues and Santos 2008, Recoder et al. 2014). In the last few decades the fields of systematics and taxonomy have been revitalized and transformed by the confluence of phylogenetic thinking and more universal access to the tools of molecular analysis (Padial et al. 2010).

Nothobachia is monotypic, containing only N. ablephara Rodrigues, 1984. The species is characterized by an extremely elongated body with reduced limbs, absence of eyelids and external ear opening, and fossorial and diurnal habits. Within the Gymnophthalmini tribe, the 
morphological and molecular data indicate that $N$. ablephara is closely related to two other genera, Calyptommatus and Scriptosaura, which in addition to other characters, share striking reduction of limbs, absence of eyelids and an external ear opening (Rodrigues 1991a, Pellegrino et al. 2001, Rodrigues and Santos 2008, Goicoechea et al. 2016). Nothobachia ablephara is endemic to semi-arid Caatinga of northeastern Brazil and occurs in the sand dune fields of Xique-Xique and Alagoado and in small sandy patches in southern Piauí and Pernambuco states, west of the San Francisco River.

Siedchlag et al. (2010) sought to understand phylogeographic patterns in fossorial microteiid lizards in the dunes of São Francisco based on molecular data of the mitochondrial cytochrome b gene $(c y t b)$ and segments of the ribosomal genes $12 \mathrm{~S}$ and $16 \mathrm{~S}$. These authors found a marked divergence (i.e., 6-8\% in combined mtDNA) between populations of Nothobachia ablephara from the dune fields of Xique-Xique and Alagoado. This divergence was about ten times greater than the divergence found among samples from three localities within the XiqueXique dune field. This difference in mtDNA suggests that the northern and southern populations of $N$. ablephara, which are separated by over $100 \mathrm{~km}$ of unsuitable habitat, diverged between three and four million years before the present (Siedchlag et al. 2010). This same pattern of differentiation was observed between populations of Eurolophosaurus divaricatus (Rodrigues, 1986) (Tropiduridae), which also is restricted to dune fields on the left bank of São Francisco river (Passoni et al. 2008). Molecular data for one specimen of $N$. ablephara from sandy patches in Petrolina, Pernambuco state, was used to place the species in the Gymnophthalmidae phylogeny (Pellegrino et al. 2001, Goicoechea et al. 2016), but these data were not used to test divergence among populations (Siedchlag et al. 2010).

Given the high molecular divergence found between populations of Nothobachia ablephara and the importance of a well-resolved taxonomy for biodiversity studies, we undertake a detailed morphological study of specimens from different populations of this species to test whether morphological differences exist that reflect the genetic divergence, and whether the differences are sufficient to warrant the recognition of distinct species.

\section{Materials and Methods}

\section{Study Area}

The sand dunes are located along the middle São Francisco River Valley in the Brazilian morphoclimatic domain of semiarid Caatinga and represent a paleodesert in northeastern Brazil (Rodrigues 1996). Mean annual temperatures exceed $26.2^{\circ} \mathrm{C}$, the highest of which is in the state of Bahia, and mean annual rain fall ranges from 400-800 $\mathrm{mm}$; typically, the dry season extends from April-September (Rocha and Rodrigues 2005). The dunes are variable in elevation (20-100 m a.s.l.) and the soils are composed mainly of eolic sand (Rodrigues 1991a, 1996). The vegetation on the dunes is greenish year-round, even in the dry season, and differs from that on the neighboring Caatinga where the appearance of the vegetation changes completely during the dry season (Rodrigues 1991a).

Lizards were collected from each of the two major sand-dune systems on the São Francisco River (Figure 1); there are molecular data documenting the divergence between the two populations. Alagoado $\left(09^{\circ} 29^{\prime} \mathrm{S}, 41^{\circ} 21^{\prime} \mathrm{W}\right)$ is in the north and Xique-Xique $\left(10^{\circ} 33^{\prime} \mathrm{S}, 43^{\circ} 19^{\prime} \mathrm{W}\right)$ in the south; the localities are separated by a region of rocky/clayish soils extending for approximately $150 \mathrm{~km}$ (Rodrigues 1991a).

\section{Data Collection}

We sampled a total of 112 adult Nothobachia ablephara from the two major sand dune fields in this study (Ramiro et al. 2017) - 34 from the south (Xique-Xique) and 78 from the north 


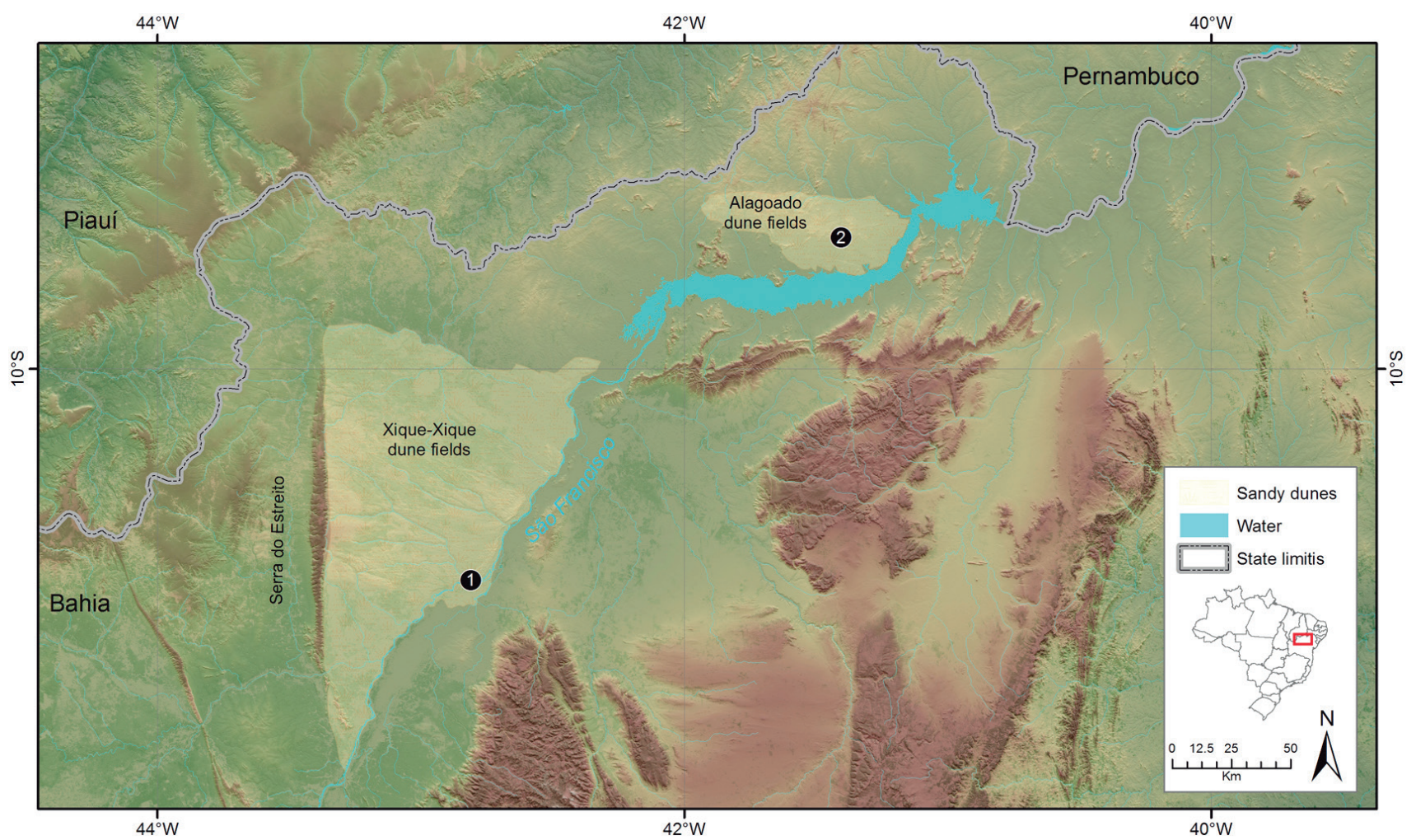

Figure 1. Geographic distribution of the samples of Nothobachia ablephara used in this study: (1) Xique-Xique (south population) and (2) Alagoado (north population), Bahia state.

(Alagoado). In addition, we examined all of the individuals housed at the herpetological collections of Museu de Zoologia da Universidade de São Paulo (MZUSP) and Laboratório de Herpetologia, Instituto de Biociências da Universidade de São Paulo (MTR), São Paulo (Appendix I).

Six measurements (to nearest $0.1 \mathrm{~mm}$ ) were taken with digital calipers from left side of preserved specimens: snout-vent length (SVL), from posterior border of cloaca to the tip of snout; trunk length (TL), between the anterior margin of hind limb to the posterior margin of forelimb; head height $(\mathrm{HH})$, at highest point in the longitudinal axis; head width (HW), at the greatest distance between the temporal scales; head length (HL), from the junction of infra and supralabial scales to the tip of snout and hindlimb length (HLL), from the insertion of the limb to the tip of the longest finger. Four scales counts were also recorded: number of scales around mid-body (SAB); number of pairs of gular scales (GUL); and numbers of transverse rows of dorsals (DOR) and ventrals (VEN). Male lizards were identified by the presence of preanal pores in males (Rodrigues 1984), and the total number of pores (POR) was recorded.

\section{Data Analysis}

We $\log _{10}$ transformed the measurements prior to analysis to meet requirements of normality (Bailey and Byrnes 1990, Zar 2010). The logtransformed morphometric data were tested for normality with Shapiro Wilk's Test and equivalence of variances with Levene's Test (Zar 2010). We assessed the Pearson correlation between the morphometric variables for both sexes in both localities.

The scale counts DOR, VEN, and SAB, deviated from normality (Shapiro Wilk's test, $p$ $<0.05)$. Thus, to evaluate differences in scale 
counts between sexes and between populations, we used the non-parametric Mann-Whitney U Test. We compared the number of gular scales (GUL) and the number of preanal pores (POR) qualitatively because little variation was observed. The arrangement of gular scales varied between even rows of gulars (symmetric) or uneven rows of gulars (asymmetric); frequencies in each population were recorded.

Because differences in sample sizes can affect statistical results and we had fewer specimens from the south (Xique-Xique), we follow a methodology suggested by Cardini et al. (2015) to evaluate the impact of sample size bias in our significance tests using the SVL of specimens from the Alagoado Dune Field. First, we checked for the presence of outliers in the samples of males and females using boxplots (not shown). For females $(N=42)$ and males $(N$ $=36$ ), the mean and the variance were calculated for the complete sample and for 10 random samples with $N=5, N=10, N=15, N=20, N$ $=25$, and $N=30$. The 61 mean and variance values calculated were plotted for each category and each sex to visualize differences between values, and then we conducted a Mann-Whitney $\mathrm{U}$ Test to evaluate whether statistical differences in significance existed between the differentsized samples.

All morphometric variables have a strong linear correlation $(\mathrm{R}>0.6)$ except the length of the hind limb (HLL) $(\mathrm{R}<0.6)$. Differences in hind-limb length (HLL) were tested with twoway analysis of variance (ANOVA) using sex and population as grouping factors. Pairwise comparisons in HLL were made using a pooled one-way ANOVA (4 groups) and post-hoc significance accessed via Tukey's HSD tests. The remaining morphometric variables, with $\mathrm{R}$ coefficients higher than 0.6 , were used in a principal component analysis (PCA) to summarize the variability in morphometric data in order to remove among-variables correlation. The PC scores that together accounted for most variation (> 95\%) were saved and used to highlight differences between both populations and sexes in those morphometric variables, with a multivariate analysis of variance (MANOVA) using the PC scores as dependent variables and sex and population as grouping factors.

We performed all statistical analyses using IBM SPSS Statistics (version 20.0, SPSS Inc., 2011).

\section{Results}

The comparative morphometric data for females and males of both populations of Nothobachia ablephara are presented in Table 1. There is sexual dimorphism in DOR and VEN (Mann-Whitney U Test, $U=0.014$ ) in both populations, and females have more scales than males in both localities (Table 1). When comparing the two populations, females differed only in VEN (Mann-Whitney U Test, $U=0.018$ ) and males differed in VEN (Mann-Whitney U Test, $U=0.001$ ) and DOR (Mann-Whitney U Test, $U=0.001$ ) scales. Females and males from the southern population have more scales than do males and females of the northern population. There were no sexual or geographic differences in SAB (Mann-Whitney U Test, U < 0.16).

There usually are seven or eight gular scales (GUL) in symmetrical rows. The northern population has seven or eight pairs of gulars in both sexes and asymmetries varying from 6-9 scales on each side. The frequency of asymmetries in this population is 0.27 for females and 0.21 for males. Males of the southern population have seven or eight pairs, but all females have seven pairs. There were asymmetries in both sexes, varying from 6-8 scales on each side. The frequency of asymmetries in this population is 0.41 for females and 0.5 for males. Males of both populations typically have six preanal pores (POR) $(N=32$ north, $N=13$ south), but some individuals have five pores $(N=3$ north, $N=2$ south) or four pores ( $N=1$ north, $N=2$ south).

In our evaluation of impact of sample size bias in significance tests, we found no significant differences between the two statistical parameters 
Table 1. External morphological measurements $(\mathrm{mm})$ and scale counts (average \pm standard deviation) of females and males of two populations of Nothobachia ablephara. $N=$ sample size, $\mathrm{HL}=$ head length, $\mathrm{HH}=$ head height, $\mathrm{HW}=$ head width, $\mathrm{TL}=$ trunk length, $\mathrm{SVL}=$ snout-vent length, $\mathrm{HLL}=$ hind limb length, $\mathrm{DOR}=$ number of dorsal scales, $\mathrm{VEN}=$ number of ventral scales and $\mathrm{SAB}=$ scales around the body.

\begin{tabular}{lcccc}
\hline & \multicolumn{2}{c}{ Nothobachia ablephara (north) } & \multicolumn{2}{c}{ Nothobachia ablephara (south) } \\
\cline { 2 - 5 } & Females $(N=42)$ & Males $(N=36)$ & Females $(N=17)$ & Males $(N=17)$ \\
\hline HL & $4.9 \pm 0.4$ & $4.5 \pm 0.3$ & $4.9 \pm 0.6$ & $4.7 \pm 0.3$ \\
HH & $2.3 \pm 0.2$ & $2.2 \pm 0.2$ & $2.3 \pm 0.3$ & $2.2 \pm 0.2$ \\
HW & $3 \pm 0.3$ & $2.7 \pm 0.2$ & $2.9 \pm 0.2$ & $2.9 \pm 0.2$ \\
TL & $40.5 \pm 3.9$ & $36.1 \pm 3.8$ & $39.8 \pm 4.7$ & $35.8 \pm 8.3$ \\
SVL & $53.3 \pm 4.9$ & $47.6 \pm 3.9$ & $53.1 \pm 6.1$ & $48.9 \pm 3.3$ \\
HLL & $5.7 \pm 0.5$ & $5.3 \pm 0.4$ & $6.1 \pm 0.5$ & $5.9 \pm 0.6$ \\
DOR & $45 \pm 1.2$ & $42.7 \pm 0.8$ & $45.3 \pm 0.9$ & $44.3 \pm 1.2$ \\
VEN & $37.3 \pm 0.9$ & $35.3 \pm 0.8$ & $37.9 \pm 1.3$ & $36.5 \pm 0.9$ \\
SAB & $19.6 \pm 0.9$ & $19.3 \pm 0.9$ & $20.1 \pm 0.9$ & $19.7 \pm 0.6$ \\
\hline
\end{tabular}

(mean and variance) estimated for SVL, among samples with different sample sizes $(N>5)$ for either females (mean: Mann-Whitney U Test, $p$ $=0.971$; variance: Mann-Whitney U Test, $p=$ 0.063 ) or males (mean: Mann-Whitney U Test, $p=0.156$; variance: Mann-Whitney U Test, $p=$ 0.358) (Figure 2). Thus, the samples were pooled in two geographic groups for subsequent analysis-Alagoado ( $N=42$ females, $N=36$ males) and Xique-Xique ( $N=17$ females, $N=$ 17 males).

Hind-limb length (HLL) varies significantly between sexes (ANOVA, $F=9.44, p=0.003$ ) and populations $(F=22.07, p<0.001)$, but sex and population did not interact significantly $(F=$ $0.30, p<0.05)$. In pairwise comparisons, females from the northern population have longer hind limbs than males (Tukey's HSD test, $p<0.01$ ), but sexes from southern population did not differ in HLL ( $p=0.433$ ) (Figure 3). Both females and males have significant geographic differences $(p$ $<0.05$ ), and lizards from the southern population have longer hind limbs than do the northern lizards (Figure 3).

The first principal component explains $80.85 \%$ of the variation in all individuals, with high and positive loadings for all morphometric variables (HL, HH, HW, LBL and SVL) (Table 2). The second component accounts for $7.53 \%$ of the variation with negative loadings for head length (HL), length between limbs (LBL) and snout-vent length (SVL). The third component explains only $6.43 \%$ of the variation, and the fourth, $4 \%$. In the morphological space of the PCA (Figure 4) the first component subtly separates females and males independent of the population, with most of the females having lower scores than males, but neither of the two components separates sexes or populations clearly.

The multivariate analysis using the first four principal components differ significantly between populations (MANOVA, $p=0.005$ ), between sexes (MANOVA, $p=0.0001$ ), and there is an interaction between sex and geography (MANOVA, $p=0.004$ ).

\section{Discussion}

Our results indicate that Nothobachia ablephara has significant geographical variation in morphology. Nevertheless, there is a general overlap in the distribution of values of the quantitative characters from Xique-Xique and 
Females
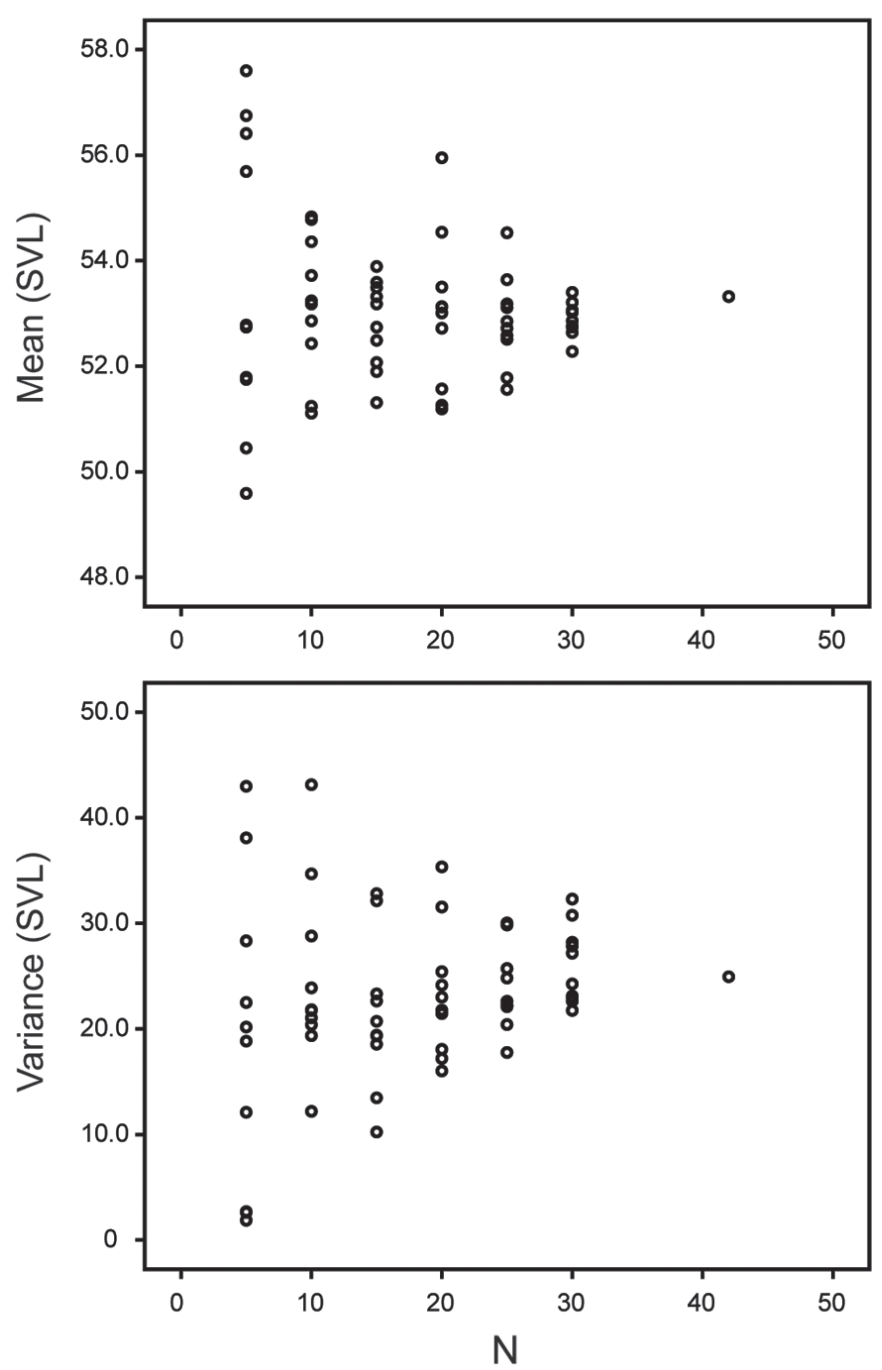

Males
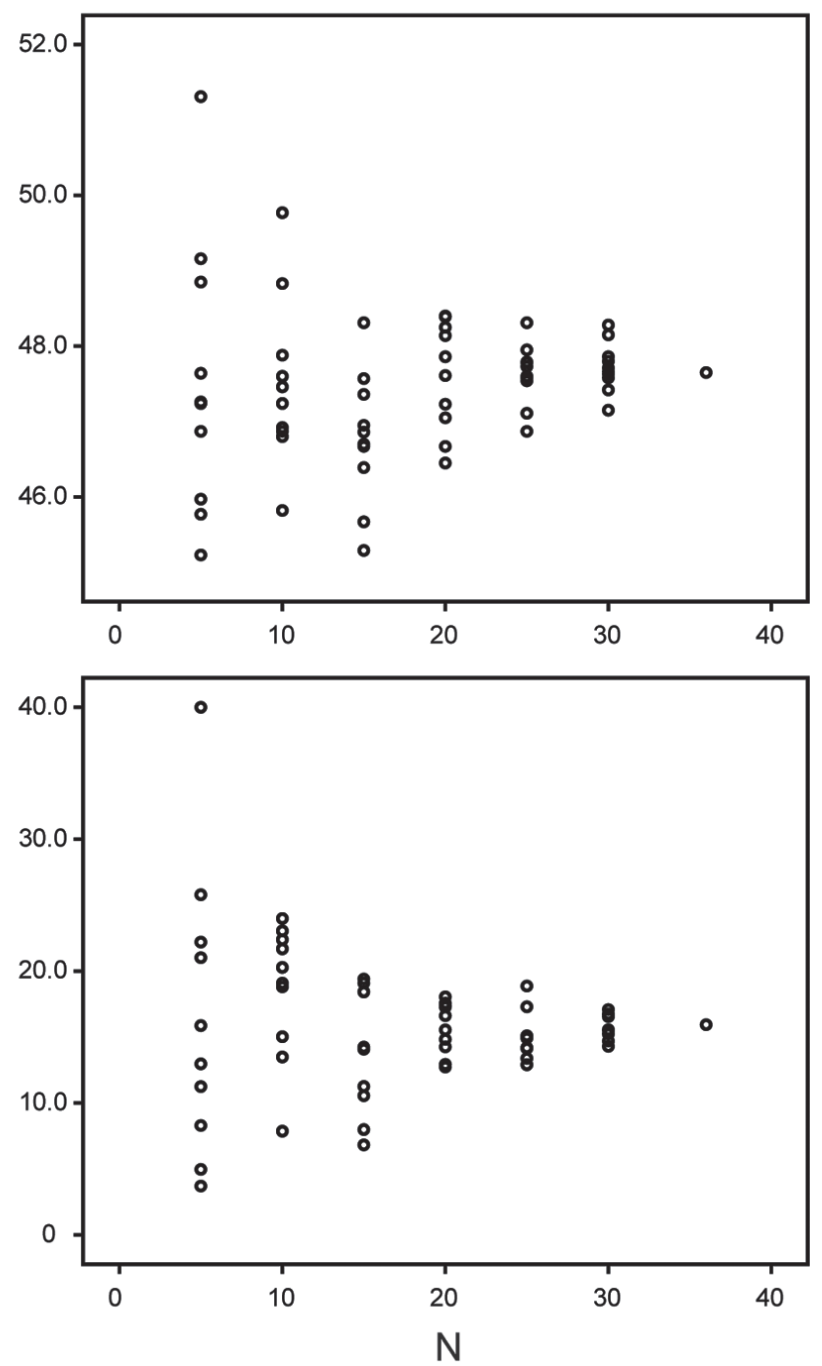

Figure 2. Effects of sample size on statistical parameters. Estimates refer to mean (upper) and variance (lower) of SVL measured for females and males of north population, based on 10 replicates for each of six subsample categories $(N=5,10,15,20,25,30)$ and total sample $(N=42$ and 36 , respectively). See text for details.

Alagoado. Therefore, the quantitative data we used in this study, which have proven useful for the taxonomy of many genera of gymnophthalmini lizards (Rodrigues 1991a-c, Ávila-Pires 1995, Recoder et al. 2014, Rodrigues et al. 2017), provide no diagnostic characters that unambiguously distinguish the two populations. Despite the significant divergence in the mDNA between the populations, we are not proposing taxonomic alterations in Nothobachia and consider it a single species (pending additional data) because the populations cannot be distinguished by diagnostic morphological characters.

Based on different studies of geographically separated organisms having a similar pattern of high molecular divergence and absence of morphological diagnostic characters, we hypothesize three major possible explanations: (1) despite long-term isolation of populations, speciation has not occurred because similar ecological conditions and low selective pressures 

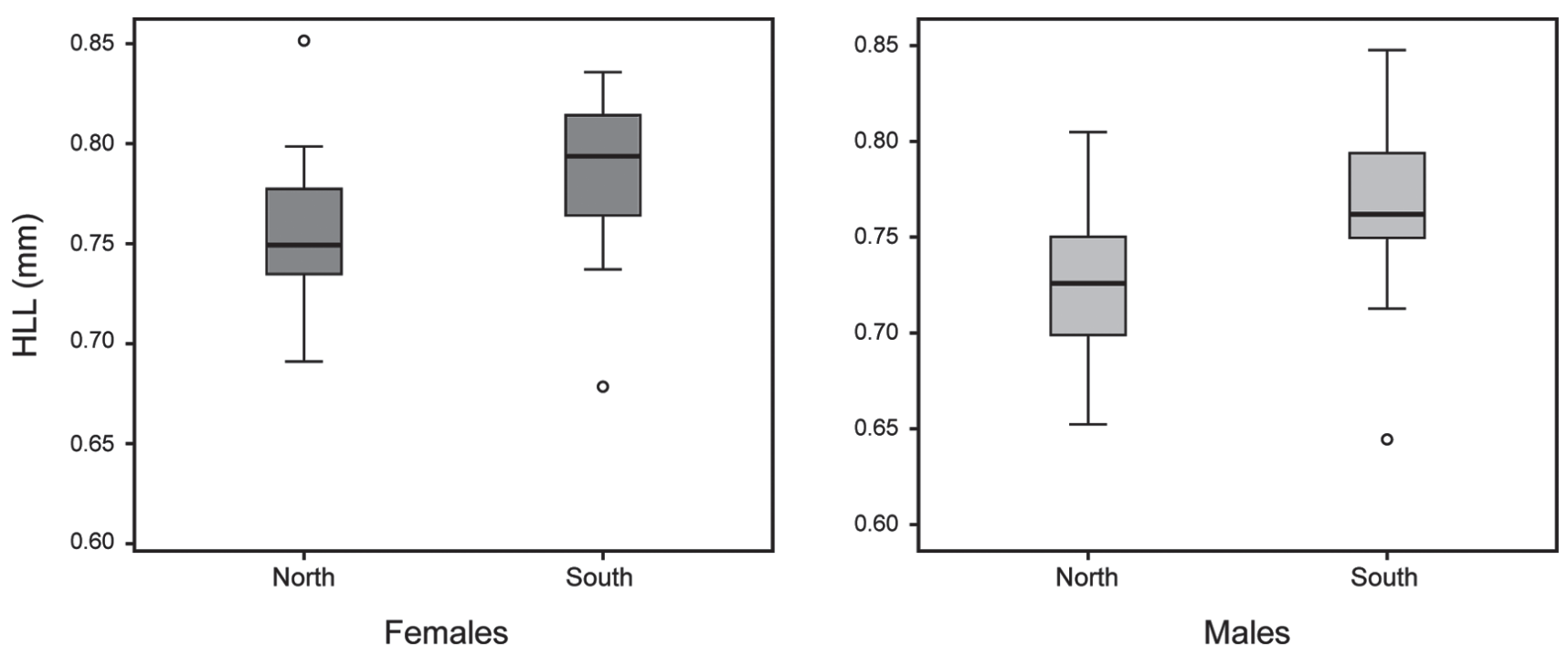

Figure 3. Boxplot of hind-limb length measurements (HLL) for females (dark gray) and males (light gray) from north and south populations.

prevail; (2) cryptic speciation has occurred; or (3) owing to secondary contact between individuals from both populations, gene-flow occurred.

Environmental conditions might impose stabilizing selection on morphology (Bickford $e t$ al. 2006); both populations of Nothobachia ablephara are under similar climatic conditions in sand dunes. Both Alagoado and Xique-Xique are characterized by high mean annual temperatures and unpredictable rain regimes, even during the wet season. However, natural history data are only available for the southern population from Xique-Xique sand dunes (Rocha and Rodrigues 2005). Thus, more ecological traits need to be studied to determine whether environmental conditions and/or niche variation have had a role in the maintenance of external morphology in populations of $N$. ablephara. Based on the possibility that environmental

Table 2. Loadings of the first four principal components of a PCA and the percentage of variation of each component for populations of Nothobachia ablephara. $\mathrm{HL}=$ head length, $\mathrm{HH}=$ head height, $\mathrm{HW}=$ head width, $\mathrm{TL}=$ trunk length and SVL = snout-vent length.

\begin{tabular}{ccccc}
\hline & PC1 & PC2 & PC3 & PC4 \\
\hline HL & 0.855 & -0.254 & 0.445 & 0.080 \\
HH & 0.871 & 0.408 & -0.012 & 0.274 \\
HW & 0.899 & 0.257 & 0.084 & -0.344 \\
TL & 0.921 & -0.225 & -0.274 & 0.042 \\
SVL & 0.947 & -0.170 & -0.203 & -0.040 \\
\hline \% Variation & 80.85 & 7.53 & 6.43 & 4.06 \\
\hline Cumulative \% & 80.85 & 88.39 & 94.82 & 98.87
\end{tabular}




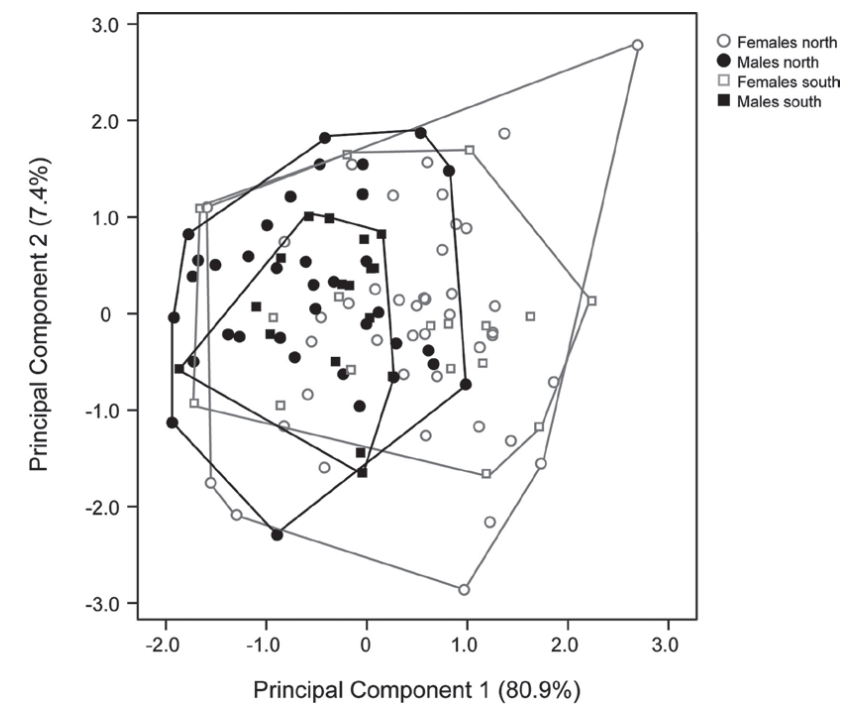

Figure 4. Results of principal component analysis (PCA) on six morphometric measurements of two samples of Nothobachia ablephara. Circles correspond to samples from the northern population, and squares to the southern population. Empty symbols correspond to females, filled symbols correspond to males.

conditions might impose stabilizing selection on morphology, it is important to notice that the other two closely related genera of fossorial lizards, Calyptommatus and Scriptosaura, also have conserved morphologies. The four recognized species of Calyptommatus, all living in sand patches around the middle São Francisco River, have highly similar external morphologies and are diagnosed mainly by head scalation and subtle differences in body-scale texture. Scriptosaura catimbau Rodrigues and Santos, 2008 is the sister taxon of $N$. ablephara and despite their different generic allocations, the species are similar in size, body shape, and color pattern.

During the past three decades, molecular data have revealed the existence of complexes of cryptic species for which it has been difficult to identify diagnosable morphological characters (Bickford et al. 2006, Siler et al. 2011), a pattern that recently seemed to be common in tropical lizards (Nunes et al. 2012, Domingos et al. 2014,
Werneck et al. 2015, Guarnizo et al. 2016, Teixeira Jr. et al. 2016). The identification of cryptic species relies largely on genetic data (Bickford et al. 2006); thus, it is important to test whether the potential cryptic lineages have restricted hybridization and complete isolation (Wake and Jockusch 2000). Frequently, mitochondrial data have been used to determinate cryptic lineages in other lizard species (Harris et al. 2002, Pinho et al. 2007, Nunes et al. 2012, Domingos et al. 2014). The divergence in mitochondrial data in Nothobachia ablephara (> $6 \%$ ) is similar to that observed for morphologically distinct species of Calyptommatus (> $3.6 \%$ ) and lower than the divergence between populations of C. leiolepis Rodrigues, 1991 from Alagoado and Xique-Xique $(<4.6 \%)$ (Siedchlag et al. 2010). Thus, cryptic diversification may also be a potential explanation for the pattern observed in $N$. ablephara, with high divergence in mitochondrial data but subtle morphological variation.

In some cases, hemipenial morphology is a key taxonomic character in investigations of cryptic speciation because of it has higher rates of evolution than do other morphological traits (Klaczko et al. 2015, D’Angiolella et al. 2016). In other species having hemipenial variation among different populations, further molecular data revealed cryptic species complexes coincident with the morphology of the hemipenis (Inger and Marx 1962, Zaher and Prudente 1999). In Iphisa elegans Gray, 1851 (Gymnophthalmidae), analysis of the morphology of the hemipenis revealed five distinct morphotypes that correspond to five wellsupported molecular clades (Nunes et al. 2012). Gabirot et al. (2010, 2012, 2013) investigated the differences in chemical sexual signs between populations of Podarcis hispanicus (Steindachner, 1870) (Lacertidae) and their importance in the process of reproductive isolation and cryptic speciation. In $P$. hispanicus, males of five populations secreted a singular and characteristic mixture of compounds used as sexual signals that can classify them. Data about the anatomy 
of the hemipenis of Nothobachia ablephara are only available for specimens from Alagoado (Nunes et al. 2014). Despite the lack of data about mating strategies, $N$. ablephara is a fossorial species, does not show sexual dimorphism in color pattern, and only males present preanal pores, that produce a large amount of secretion, indicating that the chemical communication could be an important aspect of $N$. ablephara life history. It would be interesting to test if the hemipenial morphology or the chemical characterization of the preanal glands secretions vary interpopulationally.

Given the current absence of nuclear molecular data for $N$. ablephara, we cannot determine whether the populations experienced gene-flow more recently than the time of divergence of 3-4 m.y. suggested by the mitochondrial genes (Siedchlag et al. 2010). Geological evidence suggests that the sand dune fields were formed largely in the Pleistocene during a drier, more arid climate with intense eolian activity (Tricart 1974), and that dunes are inactive and fixed in their current positions by vegetation for at least 28,000 years (Barreto 1996, Oliveira et al. 1999). Thus, we could assume that the Xique-Xique and Alagoado populations of Nothobachia have been isolated at least since the end of the Pleistocene. given the small body size of these lizards and the fidelity of the species to sand soils (Rodrigues 1984), it seems unlikely this species could disperse across about $150 \mathrm{~km}$ of typical, hardsoiled caatinga that currently separates the dune fields. Nuclear data should be analyzed to exclude the hypothesis of gene-flow postmitochondrial divergence.

In conclusion, interpopulational morphological differentiation in external characters is not significant Nothobachia ablephara, and there are insufficient molecular data to address the hypotheses on the population divergence and evolutionary history of this species. The need for an integrative, multi-trait approach that brings information about chemical composition, hemipenial morphology, fine-scale anatomy, resource use, and reproductive behavior is obvious and critical to an understanding the factors involved in geographical differentiation in $N$. ablephara and other morphologically conserved gymnophthalmid lizards.

\section{Acknowledgments}

We thank Hussam Zaher (MZUSP) and Carolina Castro-Mello (MZUSP) for access to specimens. Fundação de Amparo à Pesquisa do Estado de São Paulo (FAPESP), Conselho Nacional de Desenvolvimento Científico e Tecnológico (CNPq) and PROEX Programa de Coordenação de Aperfeiçoamento de Pessoal de Nível Superior (CAPES) provided financial support.

\section{References}

Ávila-Pires, T. C. S. 1995. Lizards of Brazilian Amazonia (Reptilia: Squamata). Zoologische Verhandelingen 299: 1-706.

Bailey, R. C. and J. Byrnes. 1990. A new, old method for assessing measurement error in both univariate and multivariate morphometric studies. Systematic Zoology 39: $124-130$.

Barreto, A. M. F. 1996. Interpretação paleoambiental do sistema de dunas fixadas do médio Rio São Francisco, Bahia. Unpublished $\mathrm{PhD}$ Thesis. Instituto de Geociências, Universidade de São Paulo, Brazil.

Bickford, D., D. J. Lohman, N. S. Sodhi, P. K. L. Ng, R. Meier, K. Winker, K. K. Ingram, and I. Das. 2006. Cryptic species as a window on diversity and conservation. Trends in Ecology and Evolution 22: 148155.

Cardini, A., K. Seetah, and G. Barker. 2015. How many specimens do I need? Sampling error in geometric morphometrics: testing the sensitivity of means and variances in simple randomized selection experiments. Zoomorphology 134: 149-163.

Castoe, T. A., T. M. Doan, and C. L. Parkinson. 2004. Data partitions and complex models in Bayesian analysis: the phylogeny of gymnophthalmid lizards. Systematic Biology 53: 448-469.

D’Angiolella, A. B., J. Klazcko, M. T. Rodrigues, and T. C. S. Ávila-Pires. 2016. Hemipenial morphology and 
diversity in South American anoles (Squamata: Dactyloidae). Canadian Journal of Zoology 94: 251256.

Doan, T. M. and T. A. Castoe. 2005. Phylogenetic taxonomy of the Cercosaurini (Squamata: Gymnophthalmidae), with new genera for species of Neusticurus and Proctoporus. Zoological Journal of the Linnean Society 145: 403-416.

Domingos, F. M. C. B., R. J. Bosque, J. Cassimiro, G. R. Colli, M. T. Rodrigues, M. G. Santos, and L. B. Beheregaray. 2014. Out of the deep: cryptic speciation in a Neotropical gecko (Squamata, Phyllodactylidae) revealed by species delimitation methods. Molecular Phylogenetics and Evolution 80: 113-124.

Ebach, M. C., A. G. Valdecasas, and Q. D. Wheeler. 2011. Impediments to taxonomy and users of taxonomy: accessibility and impact evaluation. Cladistics 27: 550557.

Estes, R., K. Queiroz, and J. Gauthier. 1988. Phylogenetic relationships within Squamata. Pp. 119-281 in R. Estes and G. Pregill (ed.), Phylogenetic Relationships of the Lizard Families. Redwood City. Stanford University Press.

Gabirot, M., P. López, and J. Martín. 2012. Differences in chemical sexual signals may promote reproductive isolation and cryptic speciation between Iberian Wall lizards populations. Journal of Evolutionary Biology 2012: 1-13.

Gabirot, M., P. López, and J. Martín. 2013. Female mate choice based on pheromone content may inhibit reproductive isolation between distinct populations of Iberian Wall lizards. Current Zoology 59: 210-220.

Gabirot, M., A. M. Castilla, P. López, and J. Martín. 2010. Differences in chemical signals may explain species recognition between an island lizard, Podarcis atrata, and related mainland lizards, P. hispanica. Biochemical Systematics and Ecology 38: 521-528.

Goicoechea, N., D. R. Frost, I. De la Riva, K. C. M. Pellegrino, J. Sites Jr., M. T. Rodrigues, and J. M. Padial. 2016. Molecular systematics of teioid lizards (Teioidea / Gymnophthalmoidea: Squamata) based on the analysis of 48 loci under tree-alignment and similarity-alignment. Cladistics 32: 1-48.

Guarnizo, C. E., F. P. Werneck, L. G. Giugliano, M. G. Santos, J. Fenker, L. Sousa, A. B. D’Angiolella, A. R. Santos, C. Strüssmann, M. T. Rodrigues, T. F. DoradoRodrigues, T. Gamble, and G. R. Colli. 2016. Cryptic lineages and diversification of an endemic anole lizard (Squamata, Dactyloidae) of the Cerrado hotspot. Molecular Phylogenetics and Evolution 94: 279-289.
Harris, D. J., S. Carranza, E. N. Arnold, C. Pinho, and N. Ferrand. 2002. Complex biogeographical distribution of genetic variation within Podarcis wall lizards across the Strait of Gibraltar. Journal of Biogeography 29: 12571262.

Inger, R. F. and H. Marx. 1962. Variation of hemipenis and cloaca in the colubrid snake Calamaria lumbricoidea. Systematic Zoology 11: 32-38.

Klaczko, J., T. Ingram, and J. Losos. 2015. Genitals evolve faster than other traits in Anolis lizards. Journal of Zoology 295: 44-48.

Marques-Souza, S., I. Prates, A. Fouquet, A. Camacho, P. J. R. Kok, P. M. S. Nunes, F. Dal Vechio, R. S. Recoder, N. Mejia, M. Teixeira-Jr., C. Barrio-Amorós, J. Cassimiro, J. D. Lima, M. A. Sena, and M. T. Rodrigues. 2018. Reconquering the water: evolution and systematics of South and Central American aquatic lizards (Gymnophthalmidae). Zoologica Scripta 47: $255-265$.

Moravec, J., J. Šmíd, J. Štundl, and E. Lehr. 2018. Systematics of Neotropical microteiid lizards (Gymnophthalmidae, Cercosaurinae), with the description of a new genus and species from the Andean montane forests. ZooKeys 774: 105-139.

Nunes, P. M. S., F. F. Curcio, J. G. Roscito, and M. T. Rodrigues. 2014. Are hemipenial spines related to limb reduction? A spiny discussion focused on Gymnophthalmid lizards (Squamata: Gymnophthalmidae). Anatomical Record-Advances in Integrative Anatomy and Evolutionary Biology 297: 482-495.

Nunes, P. M. S., A. Fouquet, F. F. Curcio, P. J. R. Kok, and M. T. Rodrigues. 2012. Cryptic species in Iphisa elegan Gray, 1851 (Squamata: Gymnophthalmidae) revealed by hemipenial morphology and molecular data. Zoological Journal of the Linnean Society 166: 361376.

Oliveira, P. E., A. M. F. Barreto, and K. Suguio. 1999. Late Pleistocene / Holocene climatic and vegetational history of the Brazilian Caatinga: the fossil dunes of the middle São Francisco River. Paleogeography, Palaeoclimatology, Palaeoecology 152: 319-337.

Padial, J. M., A. Miralles, I. De la Riva, and M. Vences. 2010. The integrative future of taxonomy. Frontiers in Zoology 7: 1-14.

Passoni, J. C., M. L. Benozzati, and M. T. Rodrigues. 2008. Phylogeny, species limits, and biogeography of the Brazilian lizards of the genus Eurolophosaurus (Squamata: Tropiduridae) as inferred from mitochondrial DNA sequences. Molecular Phylogenetics and Evolution 46: 403-414. 
Pellegrino, K. C. M., M. T. Rodrigues, Y. YonenagaYassuda, and J. W. Sites. 2001. A molecular perspective on the evolution of microteiid lizards (Squamata, Gymnophthalmidae), and a new classification for the family. Biological Journal of the Linnean Society 74: 315-338.

Pianka, E. R. and L. J. Vitt. 2003. Lizards: Windows to the Evolution of Diversity. Berkeley. University of California Press. 348 pp.

Pinho, C., D. J. Harris, and N. Ferrand. 2007. Comparing patterns of nuclear and mitochondrial divergence in a cryptic species complex: the case of Iberian and North African wall lizards (Podarcis, Lacertidae). Biological Journal of the Linnean Society 91: 121-133.

Ramiro, C. N., M. Teixeira Jr., and M. T. Rodrigues. 2017. Reproductive biology of three sympatric species of Gymnophthalmid lizards from the sand dunes of the Middle São Francisco River, Habia, Brazil. South American Journal of Herpetology 12: 76-88.

Recoder, R. S., F. P. Werneck, M. Teixeira Jr., G. R. Colli, J. W. Sites Jr., and M. T. Rodrigues. 2014. Geographic variation and systematic review of the lizard genus Vanzosaura (Squamata, Gymnophthalmidae), with the description of a new species. Zoological Journal of the Linnean Society 171: 206-225.

Rocha, P. L. B. and M. T. Rodrigues. 2005. Electivities and resource use by an assemblage of lizards endemic to the dunes of the São Francisco River, northeastern, Brazil. Papéis Avulsos de Zoologia 45: 261-284.

Rodrigues, M. T. 1984. Nothobachia ablephara: novo gênero e espécie do nordeste do Brasil (Sauria: Teiidae). Papéis Avulsos de Zoologia 35: 361-366.

Rodrigues, M. T. 1991a. Herpetofauna das dunas interiores do Rio São Francisco, Bahia, Brasil. I. Introdução à área e descrição de um novo gênero de microteiideos (Calyptommatus) com notas sobre sua ecologia, distribuição e especiação (Sauria, Teiidae). Papéis Avulsos de Zoologia 37: 285-320.

Rodrigues, M. T. 1991b. Herpetofauna das dunas interiores do Rio São Francisco, Bahia, Brasil. II. Psilophthalmus: um novo gênero de microteiidae sem pálpebra (Sauria, Teiidae). Papéis Avulsos de Zoologia 37: 321-327.

Rodrigues, M. T. 1991c. Herpetofauna das dunas interiores do Rio São Francisco, Bahia, Brasil. III. Procellosaurinus: um novo gênero de microteiídeos sem pálpebra, com a redefinição do gênero Gymnophthalmus (Sauria, Teiidae). Papéis Avulsos de Zoologia 37: 329-342.
Rodrigues, M. T. 1996. Lizards, snakes, and amphisbaenians from the Quaternary sand dunes of the middle Rio São Francisco, Bahia, Brazil. Journal of Herpetology 30: $513-523$.

Rodrigues, M. T. and E. M. Santos. 2008. A new genus and species of eyelid-less and limb reduced gymnophthalmid lizard from the northeastern Brazil (Squamata, Gymnophthalmidae). Zootaxa 1873: 50-60.

Rodrigues, M. T., H. Zaher, and F. F. Curcio. 2001. A new species of lizard, genus Calyptommatus, from the Caatingas of the state of Piauí, northeastern Brazil (Squamata, Gymnophthalmidae). Papéis Avulsos de Zoologia 41: 529-546.

Rodrigues, M. T., R. Recoder, M. Teixeira Jr., J. G. Roscito, A. C. Guerrero, P. M. S. Nunes, M. A. Freitas, D. S. Fernandes, A. Bocchiglieri, F. Dal Vechio, F. S. F. Leite, C. C. Nogueira, R. Damasceno, K. C. M. Pellegrino, A. J. S. Argôlo, and R. C. Amaro. 2017. A morphological and molecular study of Psilops, a replacement name for the Brazilian microteiid lizard genus Psilophthalmus Rodrigues 1991 (Squamata, Gymnophthalmidae), with the description of two new species. Zootaxa 4286: 451-482.

Siedchlag, A. C., M. L. Benozzati, J. C. Passoni, and M. T. Rodrigues. 2010. Genetic structure, phylogeny, and biogeography of Brazilian eyelid-less lizards of genera Calyptomatus and Nothobachia (Squamata, Gymnophthalmidae) as inferred from mitochondrial DNA sequences. Molecular Phylogenetics and Evolution 56: 622-630.

Siler, C. D., A. C. Diesmos, A. C. Alcala, and R. M. Brown. 2011. Phylogeny of Philippine slender skinks (Scincidae: Brachymeles) reveals underestimated species diversity, complex biogeographical relationships, and cryptic patterns of lineage diversification. Molecular Phylogenetics and Evolution 59: 53-65.

Teixeira Jr., M., I. Prates, C. Nisa, N. S. C. Silva-Martins, C. Strüssmann, and M. T. Rodrigues. 2016. Molecular data reveal spatial and temporal patterns of diversification and cryptic new species of lowland Stenocercus Duméril \& Bibron, 1837 (Squamata: Tropiduridae). Molecular Phylogenetics and Evolution 94: 410-423.

Tricart, J. 1974. Existence de périodes sèches au Quaternaire en Amazonie et dans les regions voisines. Revue de Geomorphologie Dynamique 23: 145-158.

Uetz, P. and J. Hosek. (ed.). 2018. The Reptile Database. Electronic Database accessible at http://www.reptiledatabase.org. Captured on 20 October 2018. 
Wake, D. B. and E. L. Jockusch. 2000. Detecting species borders using diverse data sets. Pp. 95-119 in R. C. Bruce, R. G. Jaeger, and L. D. Houck (eds.), The Biology of Plethodontid Salamanders. Amsterdam. Kluwer Academic / Plenum Publishers.

Werneck, F. P., R. N. Leite, S. R. Geurgas, and M. T. Rodrigues. 2015. Biogeographic history and cryptic diversity of saxicolous Tropiduridae lizards endemic to the semiarid Caatinga. BMC Evolutionary Biology 15: $10-24$.
Wiens, J. J., M. C. Brandley, and T. W. Reeder. 2006. Why does a trait evolve multiple times within a clade? Repeated evolution of snakeline body form in squamate reptiles. Evolution 60: 123-141.

Zaher, H. and A. L. C. Prudente. 1999. Intraspecific variation of the heminpenis in Siphlophis and Tripanurgos. Journal of Herpetology 33: 698-702.

Zar, J. H. 2010. Biostatistical Analysis. $5^{\text {th }}$ Edition. Englewood Cliffs. Pearson Prentice Hall. 960 pp.

Editor: Steven Poe

Appendix I. Specimens examined.

Nothobachia ablephara: BrazIL. Bahia. Alagoado (MZUSP: 71469, 71486, 71487, 71490-71495, 71499, 71516-71521, 71523-71525, 71566, 71529-71535, 71543, 71567, 71568, 71570, 71572, 74885, 75991, 75992, 75994, 75995, 75998-76000, 76003, 76004, 76007-76010, 77870, 77871, 77948-77951, 77953-77957, and 91915-91921; MTR: 21291, 21292, and 2129421304). Brejo da Umburana (MZUSP: 80217-80220, and 80222). Ibiraba (MZUSP: 71471, 71473-71477, 71480, and 95114). Queimadas (MZUSP: 76869-76874, 76876, 76878, 77872-77875, 77940, and 77943-77947). Barra (MTR: 39038 and 39039 ). 